SR 91

\title{
CRREL
}

Special Report 91

PERFORMANCE TESTING

OF AN

AIR CUSHION VEHICLE

ON THE

GREENLAND ICE CAP

by

Gunars Abele

FEBRUARY 1966

COLD REGIONS RESEARCH \& ENGINEERING LABORATORY

HANOVER, NEW HAMPSHIRE

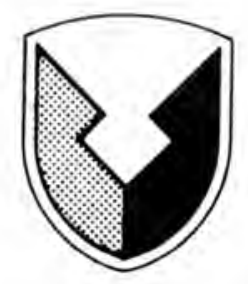


Distribution of this document is unlimited 


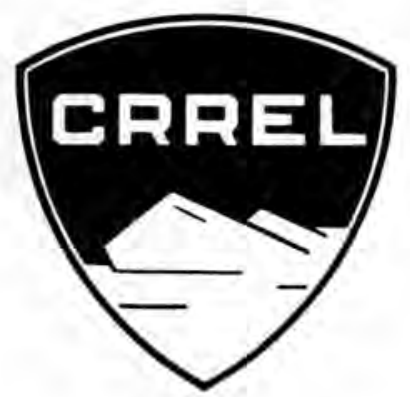

Speciai Report 91

\section{PERFORMANCE TESTING \\ OF AN \\ AIR CUSHION VEHICLE \\ ON THE \\ GREENLAND ICE CAP}

by

Gunars Abele

FEBRUARY 1966

\section{U.S. ARMY MATERIEL COMMAND}

COLD REGIONS RESEARCH \& ENGINEERING LABORATORY

HANOVER, NEW HAMPSHIRE

DA Task IV025001A13001

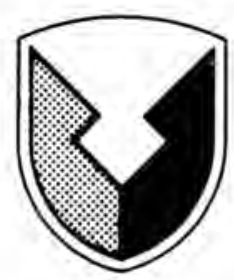


PREFACE

This work was performed as part of USA CRREL Project 6A, Development of Trafficable Surfaces (Air Cushion Vehicles), during the 1964 test season in Greenland.

The test vehicle, a tri-cell plenum air cushion vehicle (ACV), SK-3 "Carabao," was provided by the Bell Aerosystems Company, Buffalo, New York, under a contract with the U. S. Army Transportation Command (TRECOM), Fort Eustis, Virginia.

The performance testing was conducted by Gunars Abele, Research Civil Engineer, under the general supervision of Albert F. Wuori, Chief, Applied Research Branch, and by Mr. William Parrott, Chief, Measurements Systems Research Branch. The work was performed for the Experimental Engineering Division, K. A. Linell, Chief. Mr. John Hermann, under the Dartmouth College Contract, assisted in the field testing.

The Bell Aerosystems support was under the overall direction of Mr. J. B. Chaplin, Assistant Chief Engineer, Integrated Systems Engineering (responsible for $\mathrm{ACV}^{\prime} \mathrm{s}$ ) who also participated in the performance tests and in the interpretation and evaluation of the test results. The detailed technical direction during the planning and the performance testing was provided by Mr. W. McMurry who also operated the machine during the initial trials. In addition, Bell Aerosystems also provided the services of Mr. C. Olivera, Test Operator, Mr. W. Lyons, Crew Chief, and Mr, T. Lennon, Photographer.

The U. S. Army TRECOM was represented by Mr. W. Sickles.

The material presented in this report is for information only. Any use of it for promotional or advertising purposes by any commercial interest is not authorized.

USA CRREL is an Army Materiel Command laboratory.

DA Task IV025001A13001 


\section{CONTENTS}

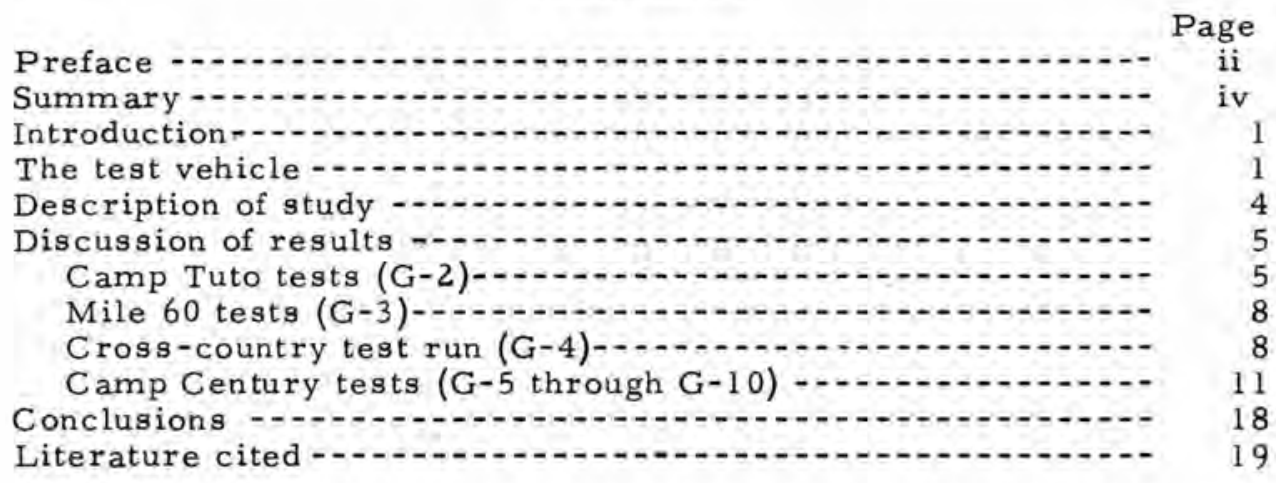

\section{ILLUSTRATIONS}

Figure

1. Tri-cell air cushion vehicle on the Greenland Ice Cap -- 2

2. Configuration of the tri-cell ACV-.... 2

3. The vehicle on a hard snow surface at Camp Tuto-..--- 6

4. Plan of Camp Tuto test area showing behavior of vehicle 7

5. Cross country test run route-... 9

6. The vehicle enroute to Camp Century $\ldots$

7. Aerial view of the vehicle 10

8. Path of vehicle showing yaw attitude using various control methods

9. The vehicle and its path after ground-out at $30 \mathrm{mph}-\ldots 14$

10. Vehicle crossing a $3 \mathrm{ft}$ wide ditch at $30 \mathrm{mph} \ldots \ldots . . . .15$

11. Vehicle crossing a $4 \mathrm{ft}$ wide ditch at $30 \mathrm{mph} \ldots \ldots . . .15$

12. Vehicle crossing a $5 \mathrm{ft}$ wide ditch at $10 \mathrm{mph} \ldots \ldots . . . . .16$

13. Apparent nose dip of vehicle at various speeds vs width of ditch-17

14. Estimated ditch crossing ability of vehicle at various

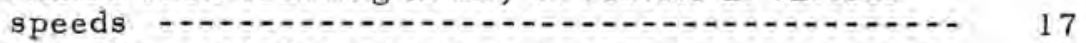

15. Profile of natural obstacle course $\ldots \ldots$

Table

TABLES

I. Specifications

II. Weather during tests 6 
During the summer of 1964 , performance tests were conducted on the Greenland Ice Cap to determine and evaluate the feasibility of the air cushion vehicle concept as a transportation method in polar regions.

Results from tests with the Bell Tri-Cell Plenum Air Cushion Vehicle indicated that the test vehicle can cruise over an undisturbed snow surface at speeds up to $35 \mathrm{mph}$ and produce a maximum speed of $42 \mathrm{mph}$.

The test vehicle was capable of ascending a 6 to $10 \%$ slope against a 15-knot wind, traveling over soft snow drifts up to 30 inches high, and crossing ditches of at least a $5-\mathrm{ft}$ width.

The payload capacity of the vehicle was approximately $1000 \mathrm{lb}$, not including the operator and fuel.

The skirt lifting sideforce concept and the harrow disk attachment proved to be very effective for control and maneuverability of the vehicle, 


\author{
PERFORMANCE TESTING OF AN AIR CUSHION VEHICLE \\ ON THE GREENLAND ICE CAP \\ by \\ Gunars Abele
}

\title{
INT RODUC TION
}

Research and military operations in the polar regions require reliable transportation methods for logistics support and personnel movement. The terrain in polar regions generally exhibits extremely poor trafficability characteristics. The supporting capacity of snow in its undisturbed state is low. In certain areas crevasses are present. These factors pose serious problems for standard surface transportation.

Air transportation is dependent on weather conditions to a much higher degree than surface methods; it is also less versatile with respect to cargo size and weight and is comparatively uneconomical. Unless ski-equipped aircraft can be utilized, adequate runways are required.

To improve surface transportation methods, three basic approaches are available:

a. Improve trafficability by altering the mechanical properties of the terrain surface to increase its traffic-supporting characteristics.

b. Improve mobility by altering the characteristics of the vehicle (such as ground pressure) or by introducing new vehicle concepts.

$$
\text { c. A combination of } \mathrm{a} \text { and } \mathrm{b} \text {. }
$$

The first approach, improving trafficability, usually involves great effort in terms of time and money and restricts traffic to a specific route. The second approach, altering the characteristics of a vehicle or even designing a new vehicle along existing mobility concepts, generally results in a low travel speed. A new mobility concept, oriented towards virtual independence from the trafficability characteristics of a surface and providing a more desirable travel speed, therefore becomes the objective. Aircraft, of course, satisfy these criteria, but not until the development of the air cushion vehicle have surface vehicle capabilities approached these requirements,

During July of 1964 a series of performance tests was conducted in Greenland to determine and evaluate the feasibility of the air cushion vehicle (occasionally referred to as the "ground effects machine") concept as a transportation method in polar regions.

\section{THE TEST VEHICLE}

The test vehicle (Fig. I) used for this study was an air cushion vehicle utilizing a tri-plenum cell concept (Fig. 2, Table I). The basic design approach, the development of the multi-plenum cell and the flexible skirt, as well as the design and performance analysis of the tri-cell prototype, have been discussed by Chaplin (1964) and will not be described here in detail. It is important to note, however, that the vehicle is of the open plenum type with no internal air ducting or exit nozzles. 


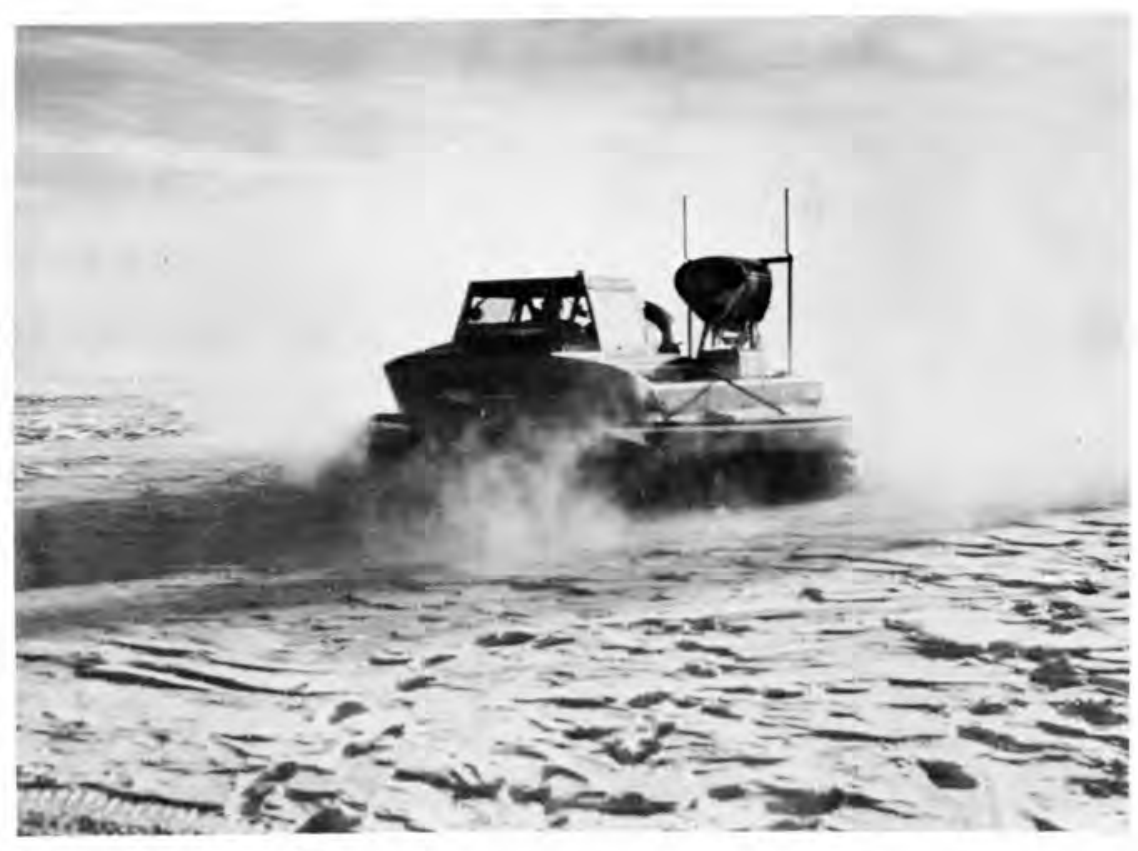

Figure 1. Tri-cell air cushion vehicle on the Greenland Ice Cap. (Photo by Bell Aerosystems Company.)

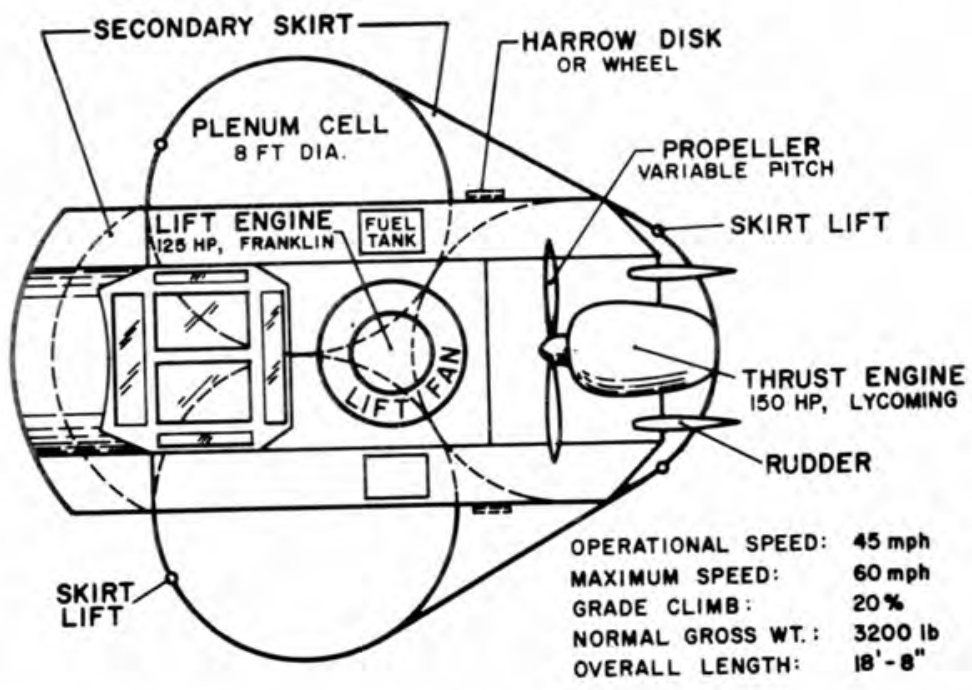

Figure 2. Configuration of the tri-cell ACV. 
Table I. Specifications.
Dimensions:
Length
Width (operating)
Width (side extensions folded)
Height
18. $7 \mathrm{ft}$
$16.0 \mathrm{ft}$
9. $7 \mathrm{ft}$
Weight: Normal gross weight
$10 \mathrm{ft}$
$3200 \mathrm{lb}$
Power plants: Lift unit-Franklin aircraft engine Cushion fan, Fiberglas
$125 \mathrm{hp}$
51 in.
Propulsion unit - Lycoming aircraft engine Propeller, two-position variable pitch
$150 \mathrm{hp}$
$6 \mathrm{ft}$
Fuel: $\quad$ Capacity in tanks
$80 \mathrm{gal}$
Type - gasoline
87 octane
Directional control:
Rudders
2
Skirt lifting sideforce control
Harrow disks (or wheels)
2
Skirts: Height
Material - Rear cell: neoprene covered terylene Right cell: nitrile covered nylon Left cell: urethane covered nylon
Secondary skirt: urethane covered nylon
18 in.
$56 \mathrm{oz} / \mathrm{yd}^{2}$
$51 \mathrm{oz} / \mathrm{yd}^{2}$
$20 \mathrm{oz} / \mathrm{yd}^{2}$
$20 \mathrm{oz} / \mathrm{yd}^{2}$
Performance (on land and water):
Operational speed
Maxímum speed
Maximum grade climbing capacity
Obstacle clearance: Wall
Hedge
Ditch

$45 \mathrm{mph}$
$60 \mathrm{mph}$
$20 \%$
$16 \mathrm{in}$.
$3 \mathrm{ft}$
$10 \mathrm{ft}$
Therefore, while the vehicle represents air cushion vehicles in general regarding the overall operating capability, the results pertaining to internal snow collection or icing are not necessarily applicable to annular jet machines.
The vehicle is equipped with two aircraft engines (see Table I), one to provide vertical lift, the other to produce horizontal thrust and braking action. The lift fan, mounted directly on the crankshaft of the engine running in a vertical position, is placed directly over the center of the three cells (Fig. 2). Each cell is fed from a segment of the fan disk. The tri-cell arrangement provides good pitch and roll stability.
Directional and yaw stability is provided by twin rudders placed in the slip- stream of the thrust engine propeller and by a skirt-lifting control, designed to enable the skirt to be lifted at four different locations on the perimeter of the tri-cell configuration. By lifting the flexible skirt at a certain place, a sideforce effect is produced by the air flow from the plenum cell through this opening. In place of the drag wheels originally installed on the vehicle, provisions were made to attach harrow disks, which, when lowered into the snow surface, would aid in directional stability and in yaw and sideslip control. 


\section{DESCRIPTION OF STUDY}

The initial performance tests of the air cushion vehicle (ACV) were conducted in the vicinity of $\mathrm{Camp}$ Tuto. The functional checkout of the engines and controls had been performed at Thule $A B$ as soon as the vehicle was assembled after shipment from CONUS. The primary purpose of the tests at Camp Tuto was to determine the general capability of the ACV to operate in an environment similar to that at Camp Century and on the ice cap as a whole. The tests consisted of the performance of the ACV on a snow surface, the maneuverability and control of the vehicle with and without the skirt-lifting sideforce control, slope-negotiation ability, and obstacle-clearing capacity.

The ACV was then transported on a sled train to Mile 60 on the Camp Tuto to Camp Century trail. A limited but essential amount of testing was performed at Mile 60 in preparation for a $78-$ mile cross country test run to Camp Century. The snow surface characteristics at Mile 60 were somewhat different from those at. Camp Tuto. The ability of the ACV to operate on this type of snow surface would be indicative of its ability to make a long distance trip on the ice cap and would, perhaps, predict any difficulties to be expected at Camp Century.

During the test run from Mile 60 to Camp Century, various observations of vehicle performance were made, namely, the maneuverability and control, behavior of the vehicle while traveling over sastrugi and drifts, cruising speed, fuel consumption, amount of snow spray, visibility, and personal comfort of the operators. The maximum acceleration to which the vehicle was subjected was also recorded. A chase helicopter was utilized as a safety precaution as well as for observation and photo coverage.

At Camp Century a square test course, $0.2 \times 0.2$ miles, was laid out and marked with flagged bamboo poles. Maneuverability tests with and without the skirt-lifting sideforce and the harrow disk controls were performed around this test course. Speed tests were conducted around the course and also on straight cross-country runs. Payload tests were performed by loading the vehicle to its maximum lifting capacity, and observing speed and maneuverability with both maximum and partial loads.

For crevasse-crossing tests ditches of various sizes were constructed, with a maximum width of $5 \mathrm{ft}$ and maximum depth of $4 \mathrm{ft}$. Speeds of 10,20 and $30 \mathrm{mph}$ were used to cross each ditch. The behavior of the vehicle while crossing a ditch was observed, particularly the amount of pitch or nose dip. For the sake of safety for both the operator and the vehicle, the crevasse-crossing tests were not continued to the apparent maximum capacity of the vehicle. From the extent of nose dip and the general behavior of the vehicle, the approximate maximum crevasse crossing capacity could be extrapolated.

The obstacle-clearance capacity tests were performed on both natural and man-made obstacles. For the maximum height capacity tests, artificial snow drifts were constructed using soft snow to decrease the possibility of damaging either the vehicle or the skirts. Further testing was then conducted in various areas around Camp Century utilizing existing snow drifts and hard snow windrows created by a bulldozer while clearing the camp trail. A number of test runs were made in one particular area having mounds and drifts of varying heights and frequency. The vehicle was also driven in areas where terrain and the exact nature of obstacles were not familiar to the operator. This, however, was as much of a challenge to the operator as to the vehicle.

The acceleration and deceleration of the vehicle during the tests were recorded with a three-axis recording accelerometer installed in the cab of the vehicle. Unfortunately, the instrument did not function properly at all times and a complete record of these data could not be obtained. 
Originally it was planned to drive the ACV back to Camp Tuto after the completion of tests at Camp Century. However, because of an unfavorable weather forecast and the lack of assurance that a rescue party would be available immediately in case of difficulties on the trail, the Century to Tuto cross-country trip was cancelled. Plans for actual crevasse crossing and other tests in the Blue Ice Valley region also had to be cancelled, since the support party had already left that area.

\section{DISGUSSION OF RESULTS}

Each test period during which a series of tests was performed without shutting down the engines was designated with a code number, G-1 through G-10. The dates and weather conditions are given in Table II. Series G-I was the functional checkout of the engines and controls at Thule AB.

\section{Camp Tuto tests (G-2)}

The snow surface density in the test area varied from 0.28 to $0.37 \mathrm{~g} / \mathrm{cm}^{3}$ $\left(17.5\right.$ to $\left.23.1 \mathrm{lb} / \mathrm{ft}^{3}\right)$. Due to the high air temperature $(38 \mathrm{~F})$ and the sun, the snow was somewhat moist with a very thin, glazed crust on the surface.

After the standard pre-operational checkout at the foot of the ramp road, both engines were started, the vehicle was driven down a short, rock-covered $25 \%$ grade to a flat snow field south of the ramp road, and a setdown was made. Lift-off on the snow surface was accomplished without difficulties. During hovering no erosion was produced by the air cushion beneath the vehicle, and very little snow spray was observed. While traveling, the vehicle left virtually no tracks, and any marks left by the vehicle on the snow surface could best be described as "scratch marks" which were caused by the skirts on any surface irregularities such as sastrugi* of more than 2 -in. height.

The skirt-lifting mechanism operated properly, and the sideforce effect appeared to be of considerable value in control and maneuvering. By utilizing the sideforce, the vehicle could easily be held on course at an approximately $15^{\circ}$ yaw angle into the wind during test runs in a $90^{\circ}, 15$-knot crosswind. The vehicle was driven at speeds up to $35 \mathrm{mph}$.

The vehicle could climb grades of 6 to $10 \%$ with a speed of up to $10 \mathrm{mph}$ against a 15-knot wind. (A 10\% grade for a very short distance was the maximum available in the immediate area.) In some areas on the grade the snow surface was covered with a hard crust, and virtually no snow spray was produced (Fig. 3 ).

On a $6 \%$ sideslope a straight course could be maintained in a 15 -knot downslope crosswind using an approximately $30^{\circ}$ yaw angle and sideforce to counteract sideslip (Fig. 4).

Some difficulties, however, were encountered in controlling the vehicle when proceeding downgrade with a 15 -knot wind. Using reverse pitch on the propeller and left and right sideforce was not sufficient to slow down the vehicle when desired and still maintain heading. With the propeller in reverse pitch, the rudders are ineffective and, unless the harrow disks or wheels are used, the sideforce is the only effective means of directional control. It was decided not to use the wheels at this point of the test program to minimize any chances for a mechanical failure. It was not planned to replace the wheels with harrow disks until the tests at Camp Century.

*Sastrugi are dune-like erosion-deposition features formed by wind. 
Table II. Weather during tests.

\begin{tabular}{|c|c|c|c|c|c|c|c|}
\hline $\begin{array}{l}\text { Test } \\
\text { series }\end{array}$ & $\begin{array}{l}\text { Operating } \\
\text { time (hr) }\end{array}$ & Date & Location & $\begin{array}{l}\text { Air temp } \\
\left({ }^{\circ} \mathrm{F}\right)\end{array}$ & $\begin{array}{l}\text { Wind } \\
\text { (knots, } \\
\text { direction) }\end{array}$ & $\begin{array}{l}\text { Barometer } \\
\text { (in.) }\end{array}$ & $\begin{array}{c}\text { Visibility } \\
\text { (miles) }\end{array}$ \\
\hline $\begin{array}{l}\text { G- } 1 \\
\text { G- } 2\end{array}$ & $\begin{array}{l}1.3 \\
2.6\end{array}$ & $\begin{array}{r}29 \text { June } \\
6 \text { July }\end{array}$ & $\begin{array}{l}\text { Thule } \\
\text { Tuto }\end{array}$ & $38 \stackrel{35}{\longrightarrow} 34$ & $\begin{array}{l}10 \text { at } 90^{\circ} \\
15 \text { at } 115^{\circ}\end{array}$ & $\begin{array}{l}29.64 \\
28.89\end{array}$ & $\underset{15}{\text { unlimited }}$ \\
\hline G- 3 & 1.1 & $10 \mathrm{July}$ & Mile 60 & 23 & 5 at $22^{\circ}$ & 25.54 & $7 *$ \\
\hline G- 4 & 2.5 & $10 \mathrm{July}$ & $\begin{array}{l}\text { Mile } 60 \\
\text { Century }\end{array}$ & $\begin{array}{l}23 \\
18\end{array}$ & 5 to 7 at $22^{\circ}$ & $\begin{array}{l}25.54 \\
23.38\end{array}$ & $\begin{array}{l}7 \\
7\end{array}$ \\
\hline$G-5$ & 0.5 & 11 July & Century & 17 & 5 to 10 at $180^{\circ}$ & 23.36 & .02 \\
\hline G- 6 & 4.1 & 16 July & Century & $11 \rightarrow$ & 9 at $90^{\circ}$ & 23.32 & 7 \\
\hline G- 7 & 2. 0 & 17 July & Century & 12 & 8 at $70^{\circ}$ & 23.26 & 7 \\
\hline$G-8$ & 2.7 & 17 July & Century & 8 & 8 at $70^{\circ}$ & $\div$ & 7 \\
\hline G- 9 & 1. 0 & 18 July & Century & 18 & 8 at $120^{\circ}$ & 23.30 & 7 \\
\hline G- 10 & 2.4 & $18 \mathrm{July}$ & Century & 17 & 7 at $120^{\circ}$ & - & 7 \\
\hline
\end{tabular}

*On the ice cap during unlimited visibility conditions the figure 7 miles is used, since that represents approximately the apparent distance to the horizon from a height of $5 \mathrm{ft}$.

Figure 3. The vehicle on a hard snow surface at Camp Tuto. (Photo by Bell Aerosystems Company,) 


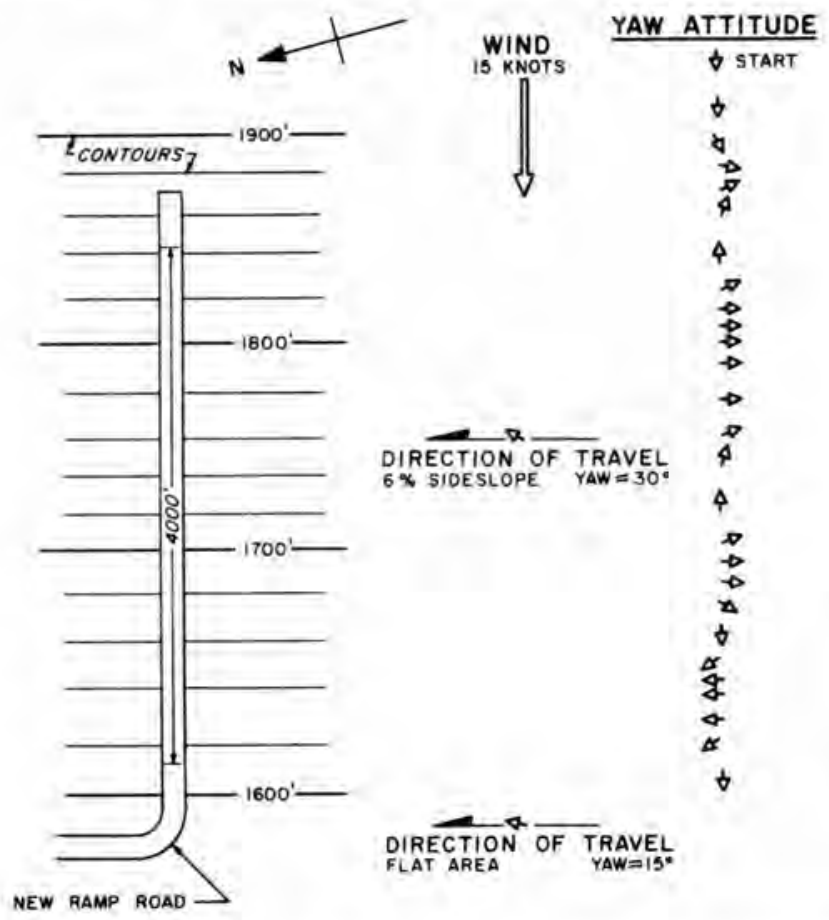

Figure 4. Plan of Camp Tuto test area showing behavior of vehicle on slope.

Better control downslope was obtained by reducing the lift fan rpm to allow only 6 to $12 \mathrm{in.}$ of operating height, dragging the skirts in snow. This is not a desirable method of control for extended periods of time because of the stresses on the skirts. To avoid this, a technique probably best described as a "falling leaf" pattern was employed for descending a long grade. When, because of the grade and wind, the vehicle had accelerated to approximately $40 \mathrm{mph}$, a $180^{\circ}$ turn was made and, while moving backwards, propeller thrust was applied to bring the vehicle to almost a hover. Then a $90^{\circ}$ turn was slowly made allowing the vehicle to drift sideways downgrade (see Fig. 4). When the vehicle exceeded a speed of $20 \mathrm{mph}$, a turn facing uphill into the wind was again made to slow down the vehicle. This was repeated as often as necessary until a level area was reached.

When necessary, the vehicle could be stopped effectively by cutting the lift power, causing the vehicle to ground-out. No skirt damage was noted after several ground-outs (some to avoid heavy equipment in the area) from speeds up to $30 \mathrm{mph}$.

During a test run to Mile 6, many obstacles were encountered. Ruts up to 30 in. deep and $24 \mathrm{in}$. wide presented no problem at speeds of $15 \mathrm{mph}$ or more. At near hover speeds, however, accidental ground-out was possible. At one point a setdown was made on these ruts. Lift-off appeared to be difficult, but after several attempts it was successfully made by using maximum propeller thrust. The importance of an experienced operator was quite evident in this situation and during the previously described descent downgrade.

Skirt drag reduced the forward speed of the vehicle while moving over 6 to 12 in. high sastrugi and drifts, but the ACV provided a more comfortable ride over this type of terrain than any other surface vehicle. At speeds of 15 mph or more, snowdrifts up to 24 in. high could be crossed without difficulty. 
A maximum speed of approximately $30 \mathrm{mph}$ was obtained while traveling towards Mile 6 against a 10 to $15-$ knot wind and a 3 to $4 \%$ grade.

An attempt to lower the wheels was unsuccessful. While negotiating downslope on reduced cushion height and during the ground-outs with the gear in the "up" position, the wheel fairing pockets had packed with snow preventing the movement of the wheels. It was also noted that the skirt pockets, located on front right and left cells to protect the skirt lift cables, had packed with snow, each pocket containing approximately $10 \mathrm{lb}$ of snow-ice.

Approximately 1 minute prior to shutdown of the lift engine, a slight vibration was felt by the operator. Inspection of the lift fan revealed that one fan blade had lost its complete metal leading edge back to the rivet point. Two other fan blades exhibited partial leading edge failure. The damaged fan was replaced with a new fan. (It was later determined that the failure was due to faulty fabrication of the metal leading edges. by a subcontractor of Bell Aerosystems and was not caused by arctic conditions.)

\section{Mile 60 tests $(\mathrm{G}-3)$}

The snow was soft with a thin, 3 to $4 \mathrm{~mm}(0.12$ to 0.16 in.) wind crust on most of the surface. The average snow density was:

\begin{tabular}{clcc}
\multicolumn{2}{c}{} & \multicolumn{2}{c}{ Depth } \\
$(\mathrm{cm})$ & (in.) & $\left(\mathrm{g} / \mathrm{cm}^{3}\right)$ & $\left(1 \mathrm{~b} / \mathrm{ft}^{3}\right)$ \\
$0-5$ & $0-2$ & 0.222 & 13.9 \\
$10-15$ & $4-6$ & 0.277 & 17.3 \\
$23-28$ & $9-11$ & 0.348 & 21.7
\end{tabular}

Both engines started normally; no heaters were required. A more noticeable snow spray than experienced at Camp Tuto was created by the lift fan. Loose snow, constantly blown by wind; on top of the wind crust was subjected to the air efflux beneath the edges of the cushion, resulting in spray. Also, not all of the snow surface was covered with wind crust. The spray, however, did not affect operation or visibility while in forward motion. No visible erosion was produced beneath the vehicle while hovering.

The undisturbed snow surface was characterized by sastrugi, 2 to 6 in, high, at an apparently random frequency. Snow drifts having a maximum height of approximately $2 \mathrm{ft}$ and sled train ski ruts up to $2 \mathrm{ft}$ deep and $2 \mathrm{ft}$ wide could be negotiated with ease. A cruising speed of 30 to $35 \mathrm{mph}$ could be maintained during test runs in this area. It appeared, therefore, that the snow surface and the ice cap terrain in general would present no great trafficability problems with an air cushion vehicle.

Cross-country test run $(\mathrm{G}-4)$

The average grade between Mile 60 (elevation $4300 \mathrm{ft}$ ) and Camp Century (elevation $6180 \mathrm{ft}$ ) is approximately $0.46 \%$; the trail distance is 78 miles. The direction of travel was $54^{\circ}$ from Mile 60 to Mile 120 , and $98^{\circ}$ from Mile 120 to Camp Century (Mile 138). The wind was approximately 5 knots at $22^{\circ}$. This caused the vehicle to travel at a 4 to $5^{\circ}$ yaw angle into the wind to Mile 120 , and at a yaw angle of approximately $8^{\circ}$ after the turn at Mile 120 (Fig. 5).

The snow surface between Mile 60 and Mile 90 was characterized by sastrugi 2 to $12 \mathrm{in.} \mathrm{high} \mathrm{and} \mathrm{occasional} \mathrm{snow} \mathrm{drifts} \mathrm{as} \mathrm{high} \mathrm{as} 24 \mathrm{in}$. The sastrugi were from 2 to $4 \mathrm{ft}$ apart, and appeared to have a "waffle" pattern at approximately $45^{\circ}$ to the direction of travel. Observed from the chase helicopter, the ACV appeared to ride smoothly. 


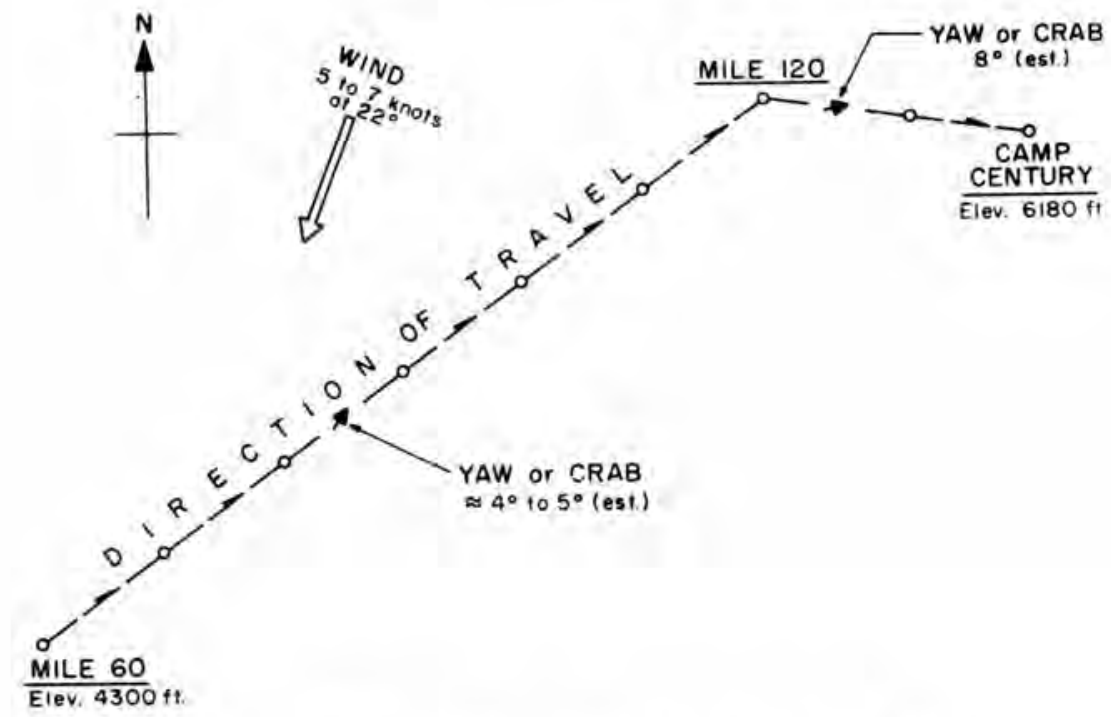

Figure 5. Cross country test run route.

Some pitch was noted while crossing drifts in the 18 to $24-\mathrm{in}$, range, and noticeable skirt drag occurred while crossing obstacles 12 or more inches high. Since the direction of snow drifts was primarily perpendicular to the direction of travel, only a small amount of roll was observed. The amount of snow spray and its pattern can be seen in Figures 6 and 7.

The section between Mile 90 and Mile 105 had more crossdrifts than the previous 30-mile section. Drifts up to $30 \mathrm{in,} \mathrm{high} \mathrm{and} 2$ to $4 \mathrm{ft}$ wide were encountered. The operators reported that the surface in this 15 -mile section caused the "bumpiest ride" in the entire route, but did not result in great discomfort.

A time check between known distance markers indicated that the vehicle was averaging a little more than $30 \mathrm{mph}$.

Between Mile 60 and Mile 105 the snow appeared to be of comparatively uniform surface hardness, generally dry and powdery with traces of a very thin wind crust on the surface. At Mile 105 the snow surface seemed to be softer than at Mile 60. After Mile 120 more wind crust was present, and the snow surface was somewhat harder. In no area was the wind crust strong enough to support a man.. Depth of footprints varied from 4 to 6 in. at Mile 60 to at least 6 in. at Mile 105 , and usually less than $4 \mathrm{in}$. at Camp Century.

From Mile 120 to Camp Century sastrugi heights rarely exceeded 6 in,, resulting in a very smooth ride with the $A C V$.

The acceleration and deceleration data recorded during the trip showed the following maximum values;

$\begin{array}{lr}\text { Forward } & 0.18 \mathrm{~g} \\ \text { Aft } & 0.06 \mathrm{~g} \\ \text { Up } & <0.5 \mathrm{~g} \\ \text { Down } & <0.5 \mathrm{~g}\end{array}$




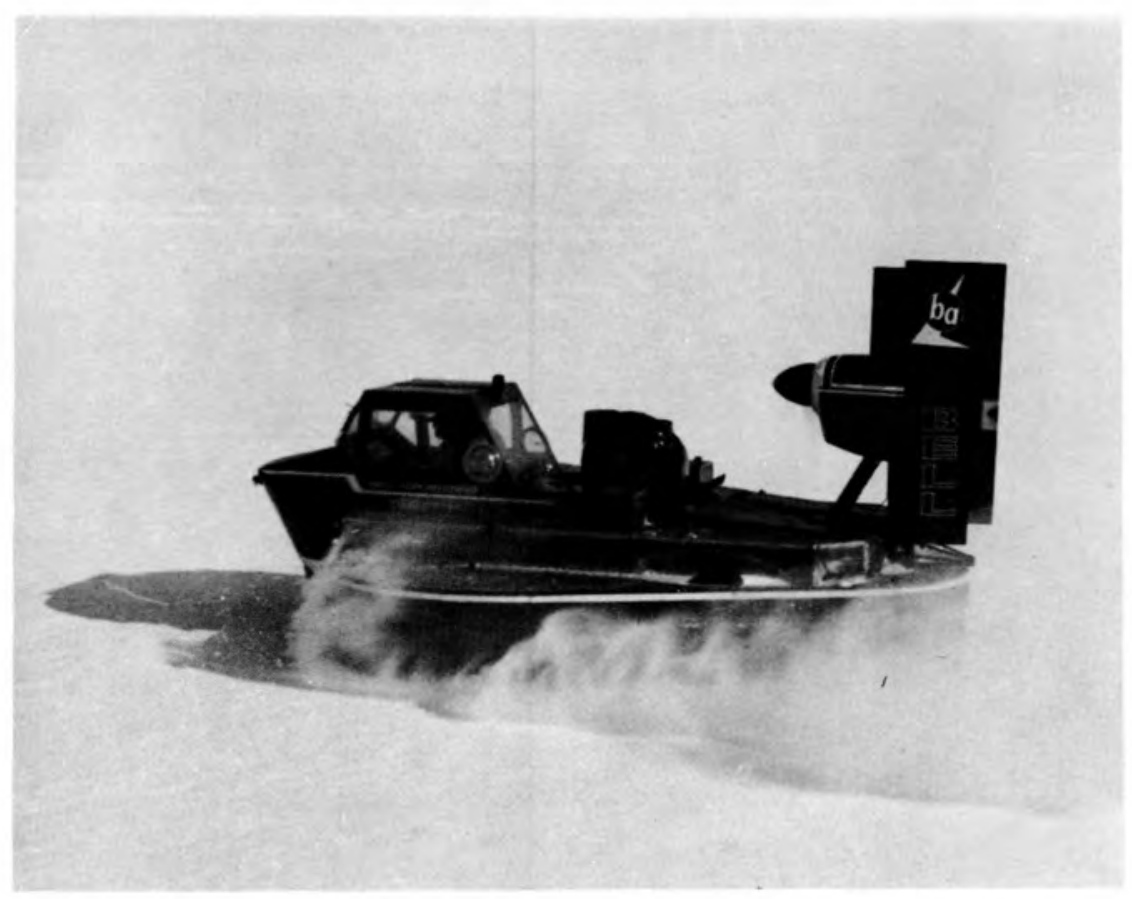

Figure 6. The vehicle enroute to Camp Century. (Photo by Bell Aerosystems Company.)

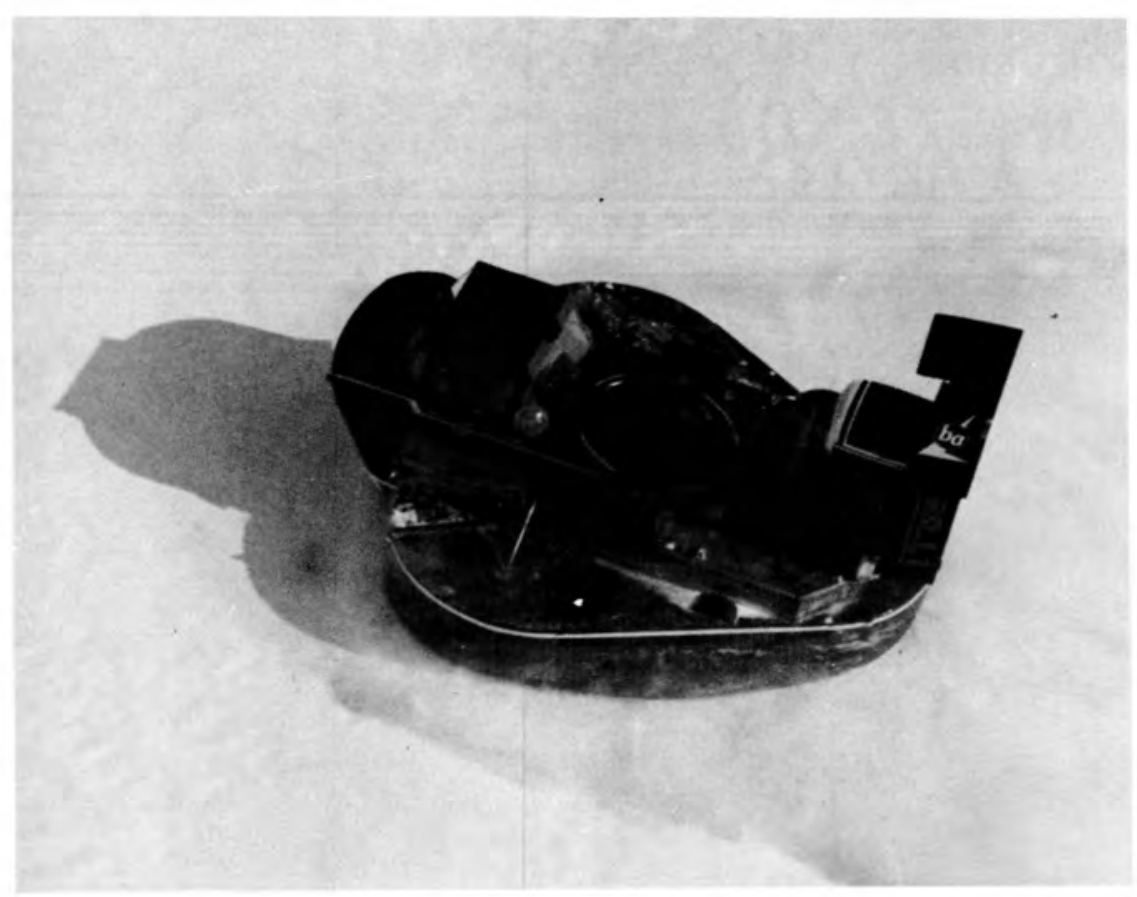

Figure 7. Aerial view of the vehicle. (Photo by Bell Aerosystems Company.) 
The 78-mile trip was completed in $2 \mathrm{hr} 25 \mathrm{~min}$, giving an average speed of $32 \mathrm{mph}$. A total of $30 \mathrm{gal}$ of fuel was used by the two engines, indicating a range of approximately 200 miles or 6.4 hours at a cruising speed of $32 \mathrm{mph}$ under these conditions. It should be noted at this point that the thrust propeller was not adjusted for high elevations.

In order to keep a constant cruise speed, periodic adjustment of the thrust engine rpm was necessary with increasing altitude. From Mile 60 to Mile 75, $2200 \mathrm{rpm}$ was used, at Mile 75 the rpm was increased to 2400 , and at Mile 120 to 2600 .

After arrival at Camp Century, it was noted that the side trusses and the wheel fairing pockets were packed with snow. It was estimated that for most of the trip the vehicle had carried 150 to $200 \mathrm{lb}$ of snow.

The vehicle left only a trace of "tracks," appearing as "scratch marks" on the crests of surface irregularities. In less than half an hour these marks were erased by wind and blowing surface snow, and it was impossible to determine where the ACV had traveled. The skirts were inspected after the trip, and no skirt wear was observed.

Camp Century tests (G-5 through G-10)

The undisturbed snow surface ( 0 to $5 \mathrm{~cm}$ or 0 to $2 \mathrm{in}$.) in the test area varied in density from $0.186 \mathrm{~g} / \mathrm{cm}^{3}\left(11.6 \mathrm{lb} / \mathrm{ft}^{3}\right)$ to $0.320 \mathrm{~g} / \mathrm{cm}^{3}\left(20.0 \mathrm{lb} / \mathrm{ft}^{3}\right)$, the average being $0.26 \mathrm{~g} / \mathrm{cm}^{3}\left(16.2 \mathrm{lb} / \mathrm{ft}^{3}\right)$. The surface ram hardness, obtained with the Rammsonde cone penetrometer, varied from 3 to 30 ; most readings were between 10 and 15 at a temperature of $17 \mathrm{~F}$.

The first trials $(G-5)$, consisting primarily of the control systems checkout, were conducted during unfavorable weather conditions. The operators became familiar with the route from the "hangar" (a cold weather tent) to the test area approximately $2500 \mathrm{ft}$ away in andisturbed area.

During prolonged hovering (G-5, G-6) no significant erosion the snow was produced after several minutes, although snow spray was present.

Maneuverability tests (G-6, G-9) showed the relative effectiveness of the sideforce and the harrow disks as an aid in directional control. Figure 8 shows the paths of the vehicle and its yaw attitudes while traveling around a rectangular course at a speed of 25 to $30 \mathrm{mph}$ using various directional control methods. These maneuverability tests were repeated several times with two different operators, and consistent results were obtained after a few trials.

It can be seen from Figure 8 that, when using only rudder and thrust control, from 150 to $250 \mathrm{ft}$ of turning room is required when entering the turn at a speed of 25 to $30 \mathrm{mph}$. Without the sideforce effect it was not possible to maintain the desired speed and negotiate the corners without drifting away from the course. When the sideforce was used, only about $50 \mathrm{ft}$ of additional distance was needed, and the next heading was achieved in considerably less time.

Besides providing improved directional control by deflection of the air cushion, the use of the skirt lift sideforce also resulted in additional skirt drag, which allowed for more effective use of the thrust, but, of course, reduced the vehicle speed.

The wind effect was an important factor. The turns at the NW and SW corners could be performed more effectively than at the NE corner because of the yaw attitude of the vehicle with respect to the wind direction. When the vehicle was headed approximately into the wind, the thrust could be used effectively. By anticipating the use of rudders and thrust, as well as the sideforce, and starting the yaw before the turn was actually encountered, unnecessary swing-out due to wind and inertia could be averted. Unless the yaw was performed sufficiently early, thus positioning the vehicle in a direction for effective use of thrust, a considerable swing-out resulted. 


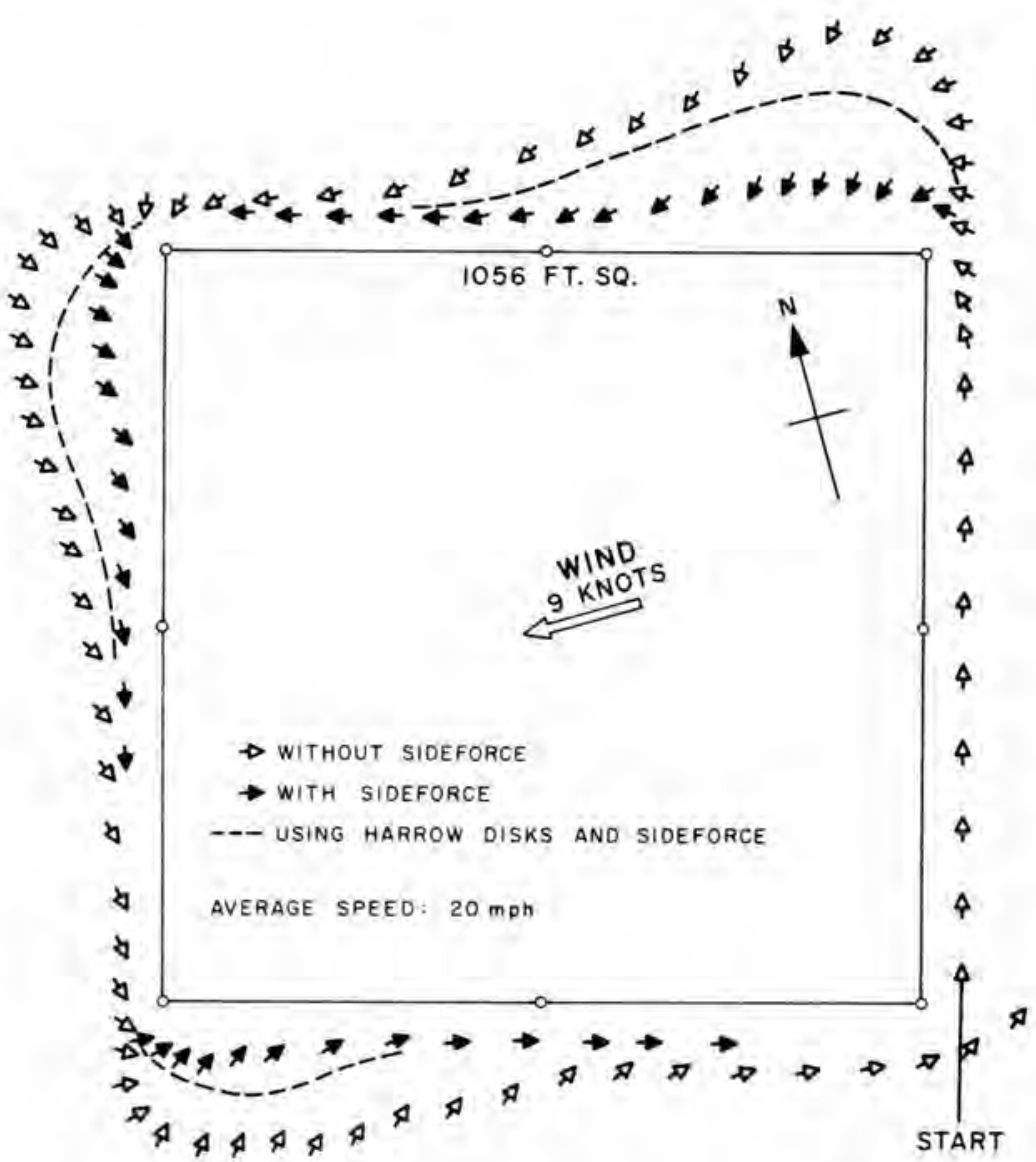

Figure 8. Path of vehicle showing yaw attitude using various control methods.

In the NE corner, after yaw to the left, the vehicle was heading with the wind, and the use of thrust was not as effective for maintaining the desired course. It was in this corner of the test course that the sideforce effectiveness was quite evident. The use of the thrust and rudder controls was most effective in the SE corner, since the vehicle was traveling into the wind. The use of the harrow disks was very effective for yaw control and for maintaining a heading in a crosswind. Maneuverability, such as the ability to make sharp turns, was decreased (see Fig, 8). Almost as much turning space was required as when making a turn without using the skirt lift. The disks, however, could be easily raised prior to a turn and lowered again when on the desired course.

The effect of the harrow disks in yaw control was tested by heading the vehicle toward a specific point with the disks up and yawing the vehicle with rudders then repeating the procedure with the disks penetrating the snow surface 4 to 5 in. The difference in yaw stiffness and in heading stabilization was apparent from the behavior of the vehicle and the disk tracks in the snow. However, a considerable reduction in speed was noticed with the disks down, and acceleration was difficult. 
Braking distance data (G-6) were obtained at vehicle speeds of 10,20 and 30 mph, both upwind and downwind. As the ACV crossed the line between two flag poles, the operator brought the vehicle to a hover (no ground-out) in the shortest possible distance by using skirt lift (aftforce) and full reverse thrust. This produced considerable yawing of the vehicle from the original heading. Better control of the vehicle during braking was obtained by moving the skirt lift control from the aft position to the side position. Thus the use of sideforce caused the vehicle to move sideways with a constant yaw attitude with respect to the original heading.

The position of the propulsion throttle before braking is an important factor. The reaction time of the reversible propeller depends on the position of the throttle. If the operator anticipates the stop and initiates braking with the throttle in the idle position, the vehicle can be stopped in a shorter distance than if the throttle is in a forward thrust position.

With the propulsion throttle in the idle or very small forward thrust position and the operator anticipating the braking action, the following results were obtained:

\begin{tabular}{c} 
Estimated speed $(\mathrm{mph})$ \\
\hline 10 \\
10 \\
20 \\
20 \\
30 \\
30
\end{tabular}

\begin{tabular}{lc} 
Direction & Braking distance (ft) \\
\cline { 2 - 2 } against wind & 60 \\
with wind & 90 \\
against wind & 75 \\
with wind & 105 \\
against wind & 84 \\
with wind & 105
\end{tabular}

The ground-out braking distance tests $(G-10)$ were performed by moving both the lift and propulsion engine throttles to the idle position. Ground-out occurs once the air cushion is dissipated. Because of the skirt drag, virtually no yaw was observed (Fig. 9). Test runs were performed only in the upwind direction.

The following results were obtained:

Estimated speed (mph)

10

20

30

\author{
Ground-out \\ braking distance (ft)
}

96

132

138

These results represent the ground-out braking distances without using reverse thrust and therefore do not represent the shortest possible distance in which the vehicle, going at a certain speed, could be stopped if an emergency arose.

No discomfort to the operator was produced during a ground-out and no apparent skirt damage resulted.

The speed tests $(G-7)$ were performed in an undisturbed area over a measured course. On a straight run, at approximately $90^{\circ}$ with an 8 -knot crosswind, a maximum speed of $42 \mathrm{mph}$ was obtained using full thrust and carrying one operator and full fuel tanks.

During the payload tests (G-8) the vehicle carried a crew of two, almost full fuel tanks, an estimated $100 \mathrm{lb}$ of snow and a specially constructed wood container on each side cell to prevent the shifting of payload during a turn. Each wood container weighed approximately $50 \mathrm{lb}$. The total weight on the vehicle, without the payload, was estimated at approximately $1200 \mathrm{ib}$. 


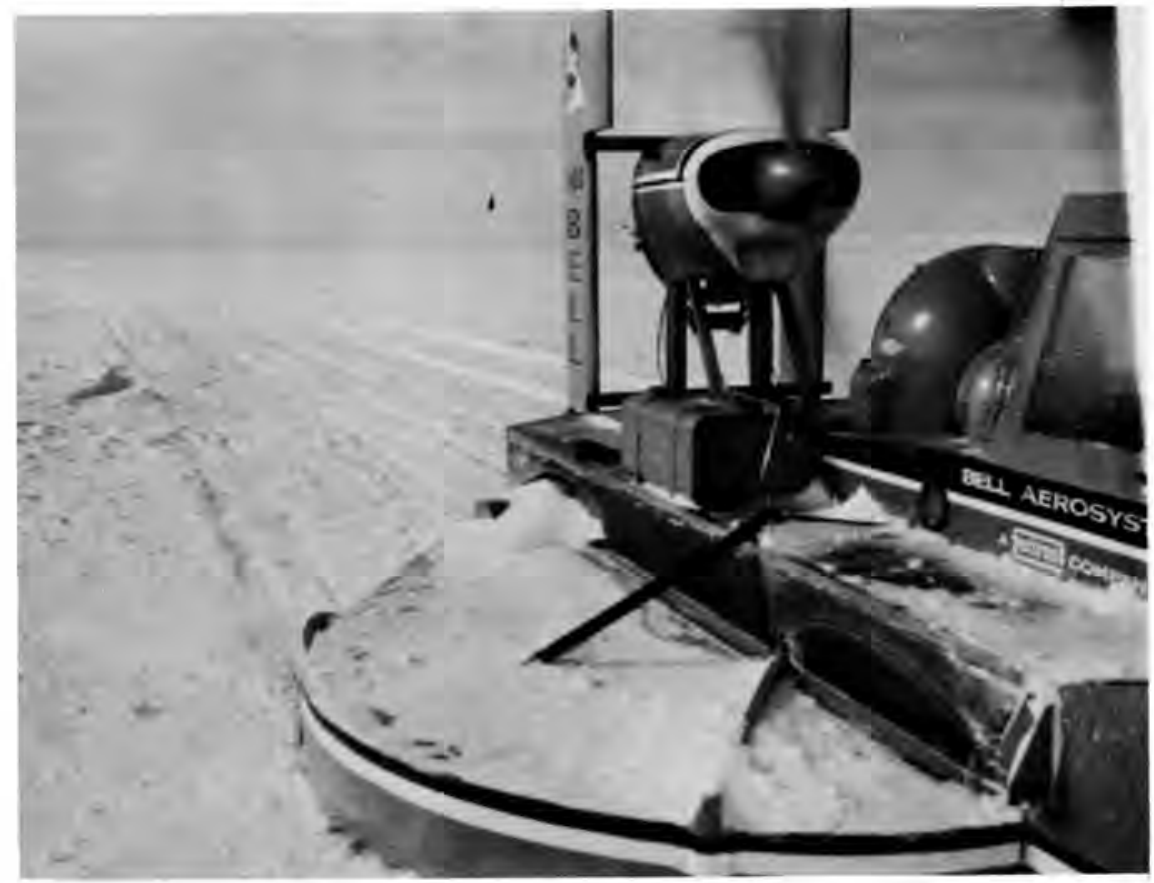

Figure 9. The vehicle and its path after ground-out at $30 \mathrm{mph}$. (Photo by Bell Aerosystems Company.)

First, a payload of $1000 \mathrm{lb}$ was placed on the vehicle (500 lb on each side cell). The rear and left cells inflated normally, but the right cell remained in a partially collapsed condition. The lift engine was at the maximum $2200 \mathrm{rpm}$. During a test run around the course, the right cell remained in a collapsed condition. An average cruising speed of $15 \mathrm{mph}$ was obtained during the test run. It was, perhaps, significant that, with the right cell collapsed, the operator was still able to perform the four left turns and negotiate the course properly. No skirt damage was observed after the test run.

The failure of the right cell to inflate under these conditions was due to the experimental material used for that particular cell. The material had stretched after fitting, causing the taper of this cell to be less than that of the other two cells. Consequently, less erecting force (the cushion pressure acting downward in the inwardly tapered skirt) was produced in this cell. (This stretching, later found to be due to the method of manufacturing this particular material, has now been eliminated.)

The payload was decreased to $450 \mathrm{lb}$ on the left cell and $400 \mathrm{lb}$ on the right cell. During the lift-off attempt, the right cell still failed to come to a full cushion position. The right cell was inflated by alternately applying forward and reverse thrust to introduce a rocking motion. Before a test run, the load on the right cell was further decreased to $350 \mathrm{lb}$. The test run was performed in a clockwise direction around the test course, obtaining an average cruising speed of $23 \mathrm{mph}$.

The crevasse crossing tests (G-7, G-10) were performed only in the upwind direction to enable the operator to have better control of the vehicle. Figures 10-12 show the ACV crossing ditches of various widths. Crossing a $2 \mathrm{ft}$ wide, $2 \mathrm{ft}$ deep ditch produced a vehicle nose dip of several inches (less than 6 in.) at $10 \mathrm{mph}, \mathrm{a}$ nose dip of a few inches at $20 \mathrm{mph}$, and very little noticeable dip at $30 \mathrm{mph}$. 


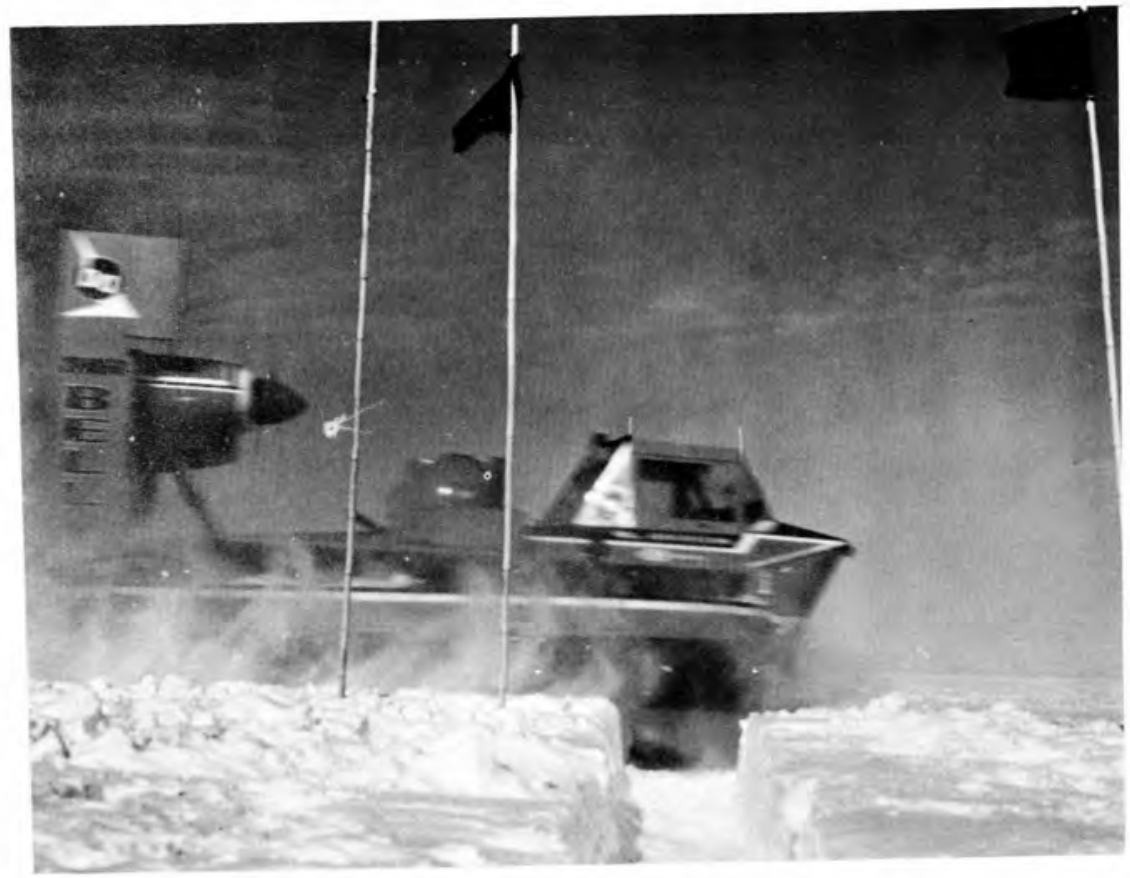

Figure 10. Vehicle crossing a $3 \mathrm{ft}$ wide ditch at $30 \mathrm{mph}$. (Photo by Bell Aerosystems Company.)

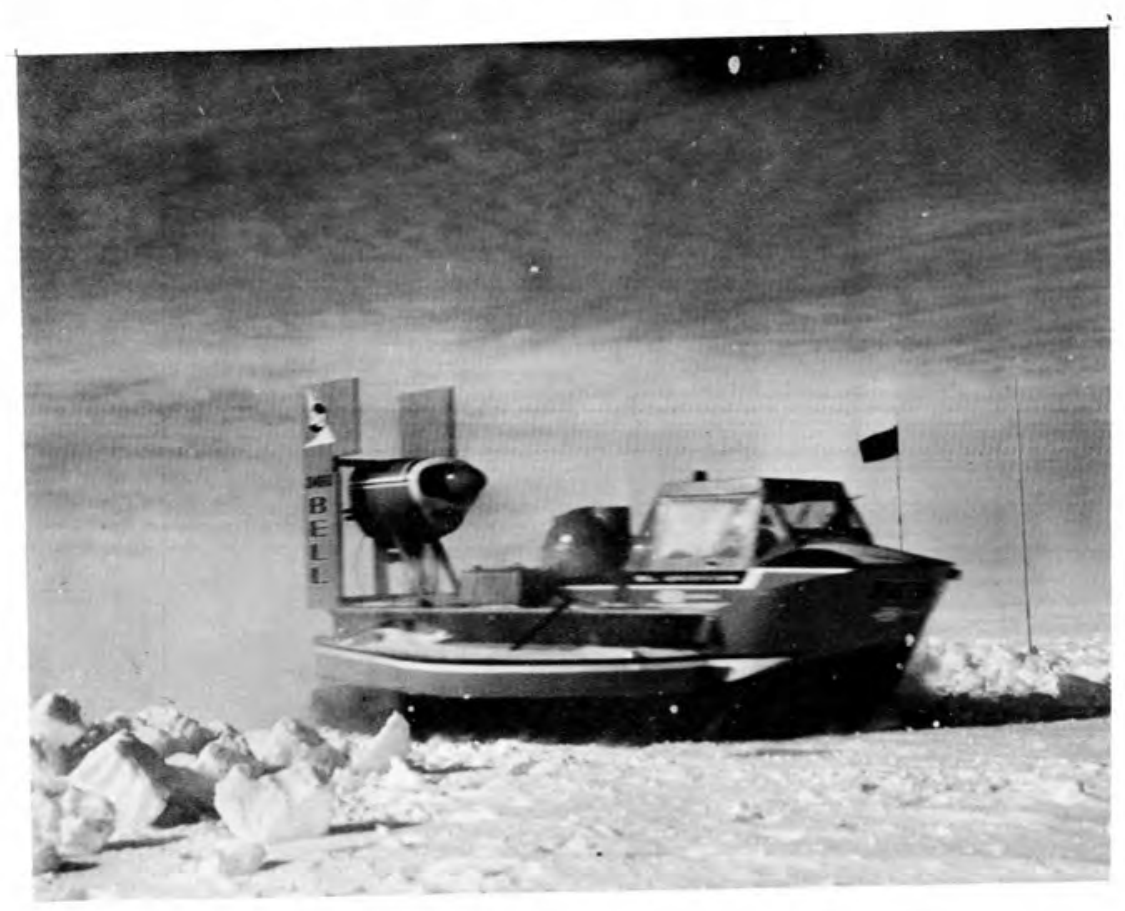

Figure 1l. Vehicle crossing a $4 \mathrm{ft}$ wide ditch at $30 \mathrm{mph}$. (Photo by Bell Aerosystems Company.) 


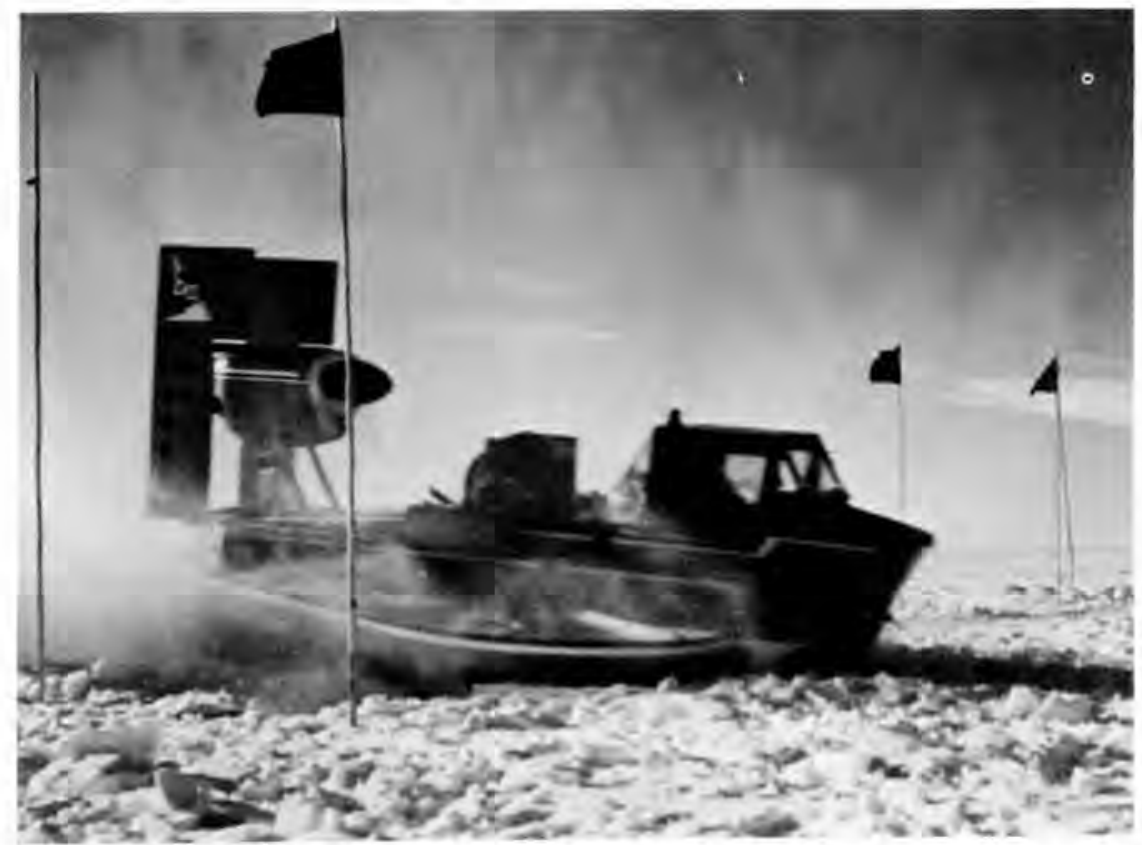

Figure 12. Vehicle crossing a $5 \mathrm{ft}$ wide ditch at $10 \mathrm{mph}$. (Photo by Bell Aerosystems Company.)

Increasing the depth to $3 \mathrm{ft}$ did not appear to affect the amount of nose dip. Increasing the width to $3 \mathrm{ft}$ did not produce significantly different results; the amount of nose dip increased by, perhaps, a few inches.

A $4 \mathrm{ft}$ wide, $2 \mathrm{ft}$ deep ditch produced a nose dip of $12 \mathrm{in}$. or more at $10 \mathrm{mph}$, somewhat less at $20 \mathrm{mph}$, and not much more than 6 in. at $30 \mathrm{mph}$. The same results were obtained when the depth was increased to $3 \mathrm{ft}$.

While crossing a $5 \mathrm{ft}$ wide, $2.5 \mathrm{ft}$ deep ditch at $10 \mathrm{mph}$ with no forward thrust applied, a nose dip of $18 \mathrm{in}$. or more was observed, the hard bottom of the vehicle hitting the opposite edge of the ditch (Fig. 12). If, however, some forward thrust was applied, causing the vehicle to accelerate slightly during the crossing, the $5 \mathrm{ft}$ wide ditch could be crossed without danger at $10 \mathrm{mph}$. At $20 \mathrm{mph}$, using some forward thrust, the nose dip was approximately $12 \mathrm{in.}$, and at $30 \mathrm{mph}$ less than 12 in.

From these tests it appeared that an increase in depth after 2 or 3 feet would not be a significant factor, i.e., a $40 \mathrm{ft}$ deep crevasse would be no more difficult to cross than a $4 \mathrm{ft}$ deep ditch. Because of the cushion dissipation time, the crosssectional area of a ditch determines whether or not the ACV can hover over the ditch and is still important for very slow speeds, but the importance of the depth of the ditch decreases as the speed increases, width becoming the limiting factor.

Visual observations relating the amount of pitch or nose dip at various vehicle speeds to the width of the ditch are shown in Figure 13. The estimated ditch crossing ability of the $\mathrm{ACV}$ at various speeds is shown in Figure 14. The results shown are only visual observations, particularly those of the amount of vehicle nose dip, and, because of the extremely short period of time (a fraction of a second) during which each observation could be made, may have an error of $\pm 25 \%$ in the opinion of the observer. The ditch dimensions are $\pm 2 \mathrm{in.}$, and the speed figures are estimated to be from $\pm 10 \%$ for $30 \mathrm{mph}$ to $\pm 20 \%$ for $10 \mathrm{mph}$. 


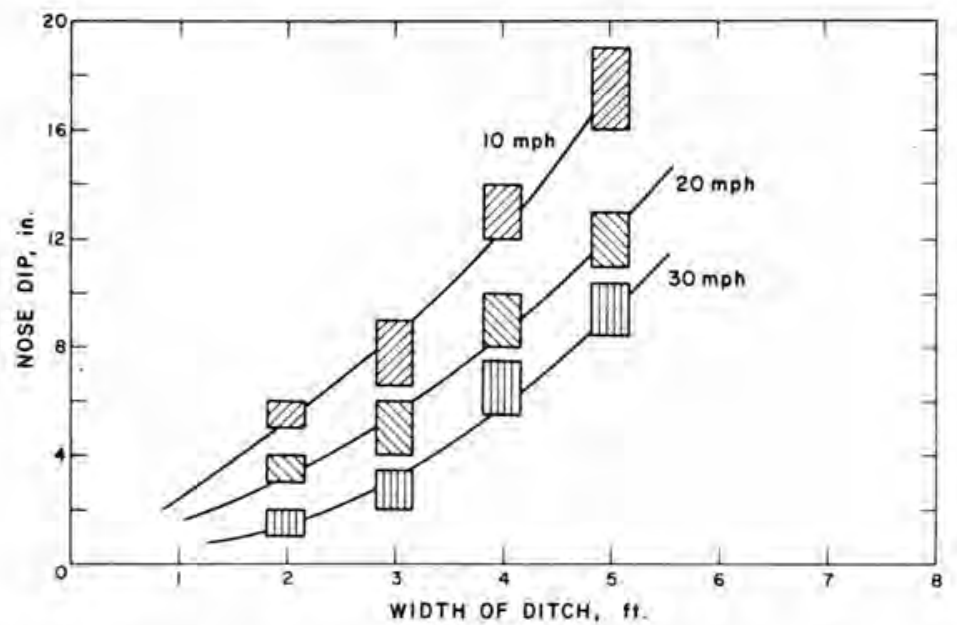

Figure 13. Apparent nose dip of vehicle at various speeds vs width of ditch,

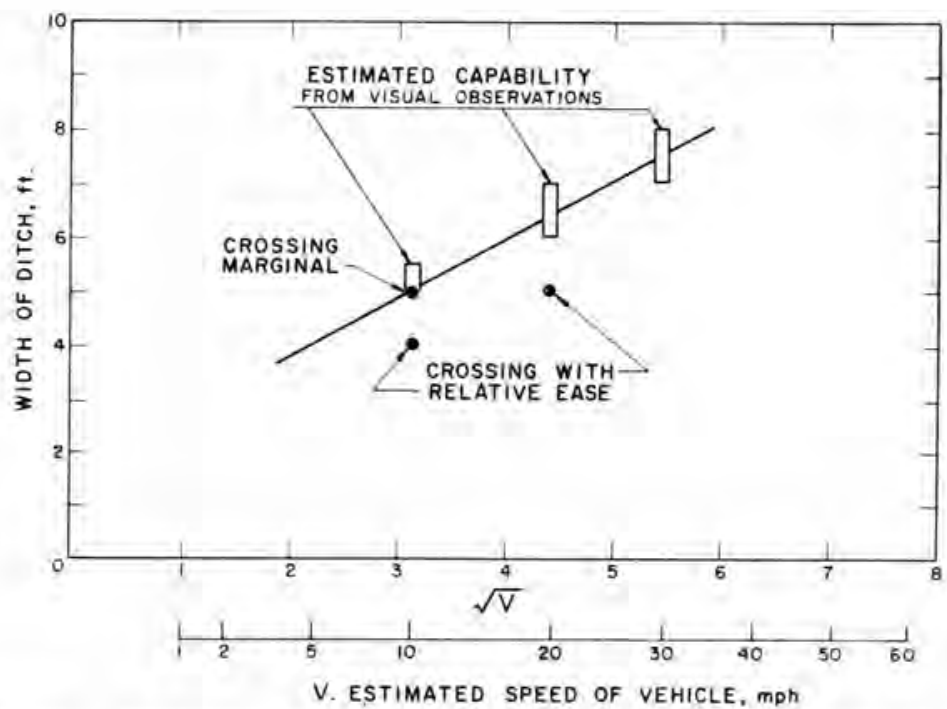

Figure 14. Estimated ditch crossing ability of vehicle at various speeds. 
During these tests ice formed in the breather pipe of the propulsion engine, causing crankcase pressurization. This pressure eventually blew the ice and a quantity of oil out of the breather pipe. However, no seal damage had occurred, and the engine performed normally during subsequent tests as long as the breather pipe was kept clear of ice.

Obstacle clearance tests (G-9, G-10) indicated that at a speed of $30 \mathrm{mph}$ the vehicle can negotiate drifts (snow density $=0.25 \mathrm{~g} / \mathrm{cm}^{3}$ or $15.6 \mathrm{lb} / \mathrm{ft}^{3}$ ) of at least a 30-in. height and 24-in. width by shearing off the crest of the drift. Crossing of very hard snow or ice obstacles is limited to the skirt height.

At speeds of 20 to $30 \mathrm{mph}$ the vehicle was also able to negotiate with comparative ease a natural obstacle course having the profile shown in Figure 15. The drifts and windrows were of hard snow, and no shearing of the crests was noticed. Test runs over this obstacle course were repeated several times, and at no time did the bottom of the vehicle or the hull come in direct contact with the snow surface. The ride in the vehicle was surprisingly smooth and comfortable compared to a wheeled or tracked vehicle.

The maximum acceleration (or deceleration) of the vehicle during a test run $(\mathrm{G}-7)$ around the rectangular test course in a counterclockwise direction at 30 mph was: $0.43 \mathrm{~g}$ forward and $0.81 \mathrm{~g}$ aft.

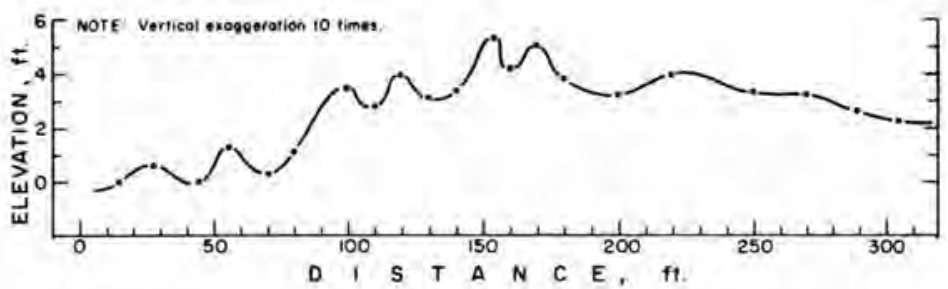

Figure 15. Profile of natural obstacle course.

Under normal operating conditions all skirts performed satisfactorily. After completion of the performance tests, no wear or damage was observed on any of the three skirt materials.

The rear cell skirt exhibited the least resistance to permanent creasing (or to taking a permanent set) during extended periods when the vehicle was not operating. The right cell skirt, as described earlier, had stretched and was more flexible than the other two materials.

\section{CONCLUSIONS}

The concept of an air cushion vehicle as a method of oversnow transportation appears to be highly feasible, primarily because of its considerable independence from the surface trafficability characteristics, its ability to negotiate obstacles smoothly, and the travel speed that can be attained over a typical polar snow surface. 
However, before the full potential of the air cushion vehicle can be evaluated, further tests are necessary. The minimum mechanical properties of a snow cover required to support an ACV have not yet been determined. Soft, fresh, loose snow conditions were not encountered in Greenland, The vehicle was not tested to its ultimate capabilities.

With the introduction of the skirt lifting sideforce control, the maneuverability of the vehicle has been increased considerably. However, this does not necessarily represent the ultimate. Even more control than presently available is highly desirable, particularly during a descent downslope. Moving the harrow disk attachment more to the rear, closer to the rudders, may result in a more effective utilization of the harrow disks.

Accumulation of snow in the frame of the vehicle and around the harrow disk attachment is detrimental to effective operation and requires corrective action. (It should be noted, however, that the vehicle was originally not designed for operation on snow.) More payload capacity is desired.

The present overall design of this vehicle may not represent the most efficient or the most effective design. The air cushion vehicle concept is comparatively new. But, although the development of air cushion vehicles has been limited to the last several years, this concept shows considerable potential as a future means of transportation,

\section{LITERATURE CITED}

Bell Aerosystems Company (1964) SK-3 Greenland evaluation operational log, prepared for the U. S. Army TRECOM, $55 \mathrm{p}$.

Chaplin, J. B. (1964) The development of a multi-cell plenum concept, Bell Aerosystems Company, Buffalo, New York, $42 \mathrm{p}$.

Princeton University Conference and the U. S. Army TRECOM (1959) Symposium on ground effect phenomena, Princeton University, $391 \mathrm{p}$.

Booz-Allen Applied Research, Inc. (1963) Operational analysis of the use of air cushion vehicles in support of the Army's off-road logistic mission, $U$. S. Army TRECOM Technical Report 63-37, 24 p. 